\title{
Lighting by Biogas Burners: Perspectives on Development in Brazil
}

\author{
Silas Cardoso Santos, Chieko Yamagata, Sonia Mello-Castanho \\ Center of Materials Science and Technology-CCTM, Nuclear and Energy Research Institute-IPEN, São Paulo, \\ Brazil \\ Email: silascs@ipen.br
}

Received 28 April 2014; revised 5 June 2014; accepted 25 June 2014

Copyright @ 2014 by authors and Scientific Research Publishing Inc.

This work is licensed under the Creative Commons Attribution International License (CC BY).

http://creativecommons.org/licenses/by/4.0/

(c) (i) Open Access

\begin{abstract}
The development of efficient components to save energy plays an important role in designing of sustainable solutions. Based on the concept of green energy, gas burners based on porous ceramic structures are interesting technologies to supply heat and lighting by burning even low calorific fuels as biogas. In this work, perspectives on development of porous ceramic burners in Brazil are presented. For this study a mixture of rare earth oxides-yttria (YTR) was selected as raw material, considering the unique luminescence proprieties of rare earth elements. Ceramic nettings with homogeneous morphology were produced by colloidal processing of rare earth powders. The results highlighted the potentiality of these components to be applied as biogas burners.
\end{abstract}

\section{Keywords}

Energy, Biogas, Rare Earth Oxides, Ceramic Processing, Rheology

\section{Introduction}

\subsection{Energy and Development}

In the present world the progress and welfare of society are directly associated with consumption of energy. According to the International Energy Agency (IEA), the demand on energy increases by 1.5\% a year, where lighting corresponds to one fifth of this demand. Further, the most alarming thing is that fossil fuels still supply almost $80 \%$ of total energy, causing several known environmental damages. On the other hand, almost 2 billion of people do not have access to energy in the world, living in extreme poverty conditions [1] [2].

The United Nations has established that the universal access to energy is one of the great global challenges in this century, since it is a basic requirement of citizenship [1] [2]. Based on this idea, Brazil introduced a program to universalize the access to energy by supporting the use of local and renewable energy sources from modern 
biomass (PROINFA [3], 2002). In addition, PROINFA is also concerned to reduce the dependence on hydroelectricity that is subject of seasonal fluctuations.

Biogas derived from anaerobic decomposition of organic wastes (urban, rural and sewage) [4] having methane $\left(\mathrm{CH}_{4}\right)$ as the main constituent (Table 1) [5] presents a considerable calorific power, which is higher than firewood and bagasse and quite similar to ethanol Figure 1. Further, many efforts have been done in order to make it suitable enough to substitute conventional fuels. Technological alternatives have been presented, as the improvement of biogas production [6]-[9] and increase of its energy efficiency [10]-[14].

A reliable path to drive the present economic pattern to a green economy consists in using modern renewable sources, as well as advanced components to improve energetic efficiency [2] [15] [16]. Considering this conception, biogas should be used as fuel for lighting by porous burners (PB) application. Burning biogas by PB avoids methane $\left(\mathrm{CH}_{4}\right)$ emission in the environment, which is twenty one times more harmful than $\mathrm{CO}_{2}[4]$. Furthermore, the combustion in PB is more efficient than a free flame, since the premixed fuel/air burns within the cavities of the porous component. The net structure works as a heat circulator, which is able to burn low calorific power fuels that would not be usually flammable by conventional process. In addition, light emission, flame speed and stability are improved [17].

By ONU's Renewables Global Status Report [18], the general concept of sustainable development consists in providing the need of the present generation, so that the capacity of the future generations to provide their own needs is assured. Therefore, the use of renewable sources, as biogas should contribute to mitigating the environmental, social and economic challenges [3] [19]. Furthermore, biogas can be a driver to establish a new economic model. Based on the three basic aspects as environmental, social and economic, Table 2 [1] [4] [18]-[20] summarizes the advantages in using biogas.

\subsection{Porous Burners for Lighting}

Many authors have discussed that the characteristics of the component play a very important role in the combustion process of the fuel, so that components with a considerable porosity are more efficient than solids ones. Porous components are bodies constituted by gaps forming a net/strut structure, wherein a matter can flow through [21]. Porous burners (PB) are technological solutions that can supply light and heat uniformly. In addition, efficient combustion process results in low emission of greenhouse gases $\left(\mathrm{NO}_{\mathrm{x}}, \mathrm{CO}\right)$. The concept of $\mathrm{PB}$ was first presented by Takeno and Sato [22] [23]. Using a porous component was possible to sustain the flame with lower fuel rates. Comparing to solid bodies, porous components have advantages such as less weight, high mechanical and combustion efficiency. Thus, they are used in many technological applications as filters for molten metals, catalysis support, chemical sensors, gas diffusors and also for gas burners [24].

The combustion of a mixture of air and fuel (natural gas, ethanol, biogas) in a PB is detailed in (Figure 2) and it can be divided in three steps. Reflux zone (1), where gas is hotter than the ceramic structure and the heat is conducted by convection from the combustion zone to the porous ceramic structure; Ceramic conduction (2),

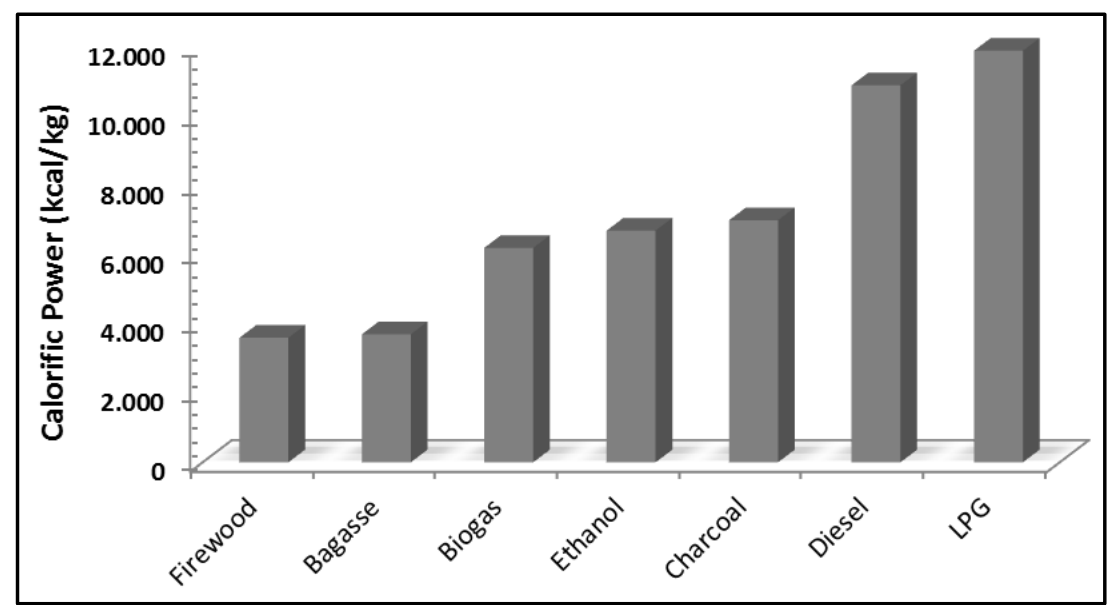

Figure 1. Comparative of calorific power of some energy sources. LPG: Liquefied petroleum gas. 
Table 1. Average composition of biogas from different organic wastes [5].

\begin{tabular}{cc}
\hline Constituents & Percentage (\%) \\
Methane $\left(\mathrm{CH}_{4}\right)$ & $40-75$ \\
Carbon dioxide $\left(\mathrm{CO}_{2}\right)$ & $25-40$ \\
Nitrogen $(\mathrm{N})$ & $0.5-2.5$ \\
Oxygen $(\mathrm{O})$ & $0.1-1$ \\
Hydrogen sulfide $\left(\mathrm{H}_{2} \mathrm{~S}\right)$ & $0.1-0.5$ \\
Ammonia $\left(\mathrm{NH}_{3}\right)$ & $0.1-0.5$ \\
Carbon monoxide $(\mathrm{CO})$ & $0-0.1$ \\
Hydrogen $(\mathrm{H})$ & $1-3$ \\
\hline
\end{tabular}

\section{Table 2. The three fundamental aspects to use biogas as energy source [1] [4] [18]-[20].}

\begin{tabular}{cl}
\hline Environmental & $\begin{array}{l}\text { Reduction of greenhouse gases, where methane }\left(\mathrm{CH}_{4}\right) \text { is } 21 \text { times more harmful than } \mathrm{CO}_{2} \text {; diversification } \\
\text { of energy matrix and gradual substitution of fossil fuels (natural gas, petroleum, charcoal); improvement } \\
\text { of air quality. }\end{array}$ \\
Social & $\begin{array}{l}\text { Diffusion of basic sanitary programs, where garbage is not a problem anymore and become an energy } \\
\text { solution; increasing of energy supply, since energy is life quality; reduction of migration from rural areas } \\
\text { to cities by production of local energy in a sustainable form. }\end{array}$ \\
Economic & $\begin{array}{l}\text { Creation of job opportunities; development of a new energy market; carbon credit (US\$150 million a year, } \\
\text { considering only bovine waste) [20] [25]. }\end{array}$ \\
\hline
\end{tabular}

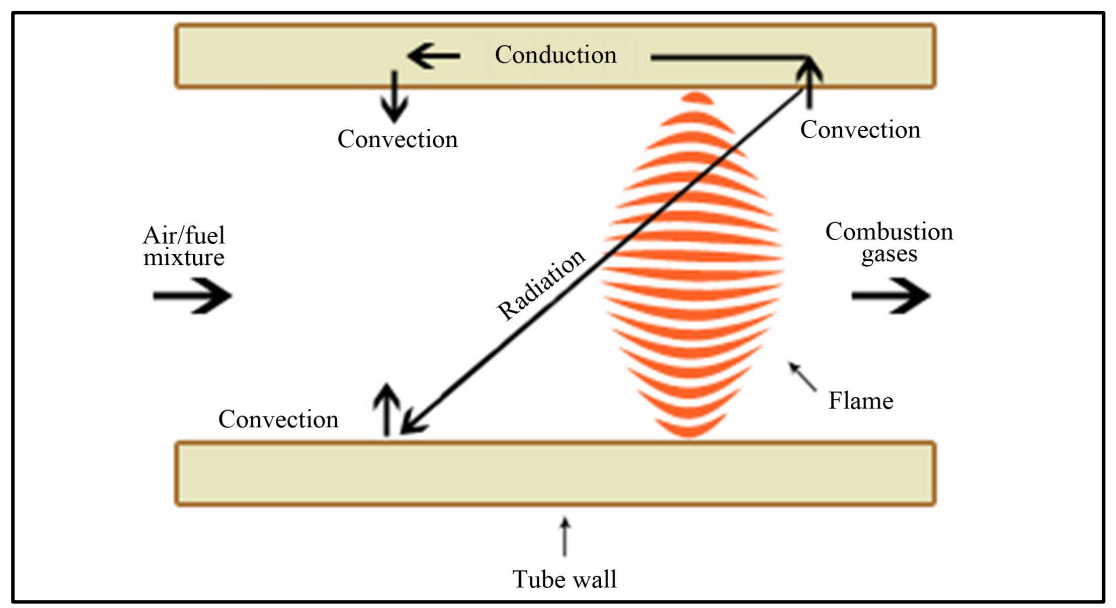

Figure 2. The process of heating circulation in a porous burner idealized as a tube [26].

where the ceramic structure conducts and irradiates the heating flow to the combustion zone; Heating of the gas (3), being the temperature of the ceramic structure higher than the gas, resulting in heat conduction by convection in solid-vapor system. In this way, the entrance gases are preheating up to the limit temperature in order to start the reaction and maintain the cycle. This system improves the velocity of the flame and also the efficiency of the combustion, resulting in lower emission of greenhouse gases [26].

\subsection{Materials and Processing}

Materials selection is an important consideration during the design of PB. Proprieties such as emissivity, corrosion resistance, thermal expansion, thermal conductivity and mechanical strength must be considered carefully. Among ceramic materials, rare earth oxides (REOs) present unique luminescent proprieties, being employed in high 
technological applications as LED panels, lasers, lens [27]-[30].

The processes commonly applied to produce porous ceramic components are sacrificial template, gel casting and replica method [31]-[34]. The last one is widely used due to its great applicability to any ceramic material that can be dispersed in suspension Figure 3. In addition, the template can be any material that can be burned out during the thermal treatment. This process allows for producing components with complex shape and with low cost. However, ceramic suspension must present a suitable rheological behavior, wherein viscosity plays an important role during the process. High viscous suspensions are not desired, once they present high resistance to flow. Thus, they cannot recover and neither enter into cavities of porous template. On the other hand, low viscous suspensions cannot remain on the surface of the template, since they flow easily. Thus, the ceramic suspension must be able to flow while subject of external force and as static condition it has to present higher viscosity. Finally, thermal treatment is extremely important. The heating rate must be also well controlled, so that the organic template can be burned out without disrupting the ceramic structure.

Even though REOs show unique luminescent proprieties, few studies about colloidal processing of these compounds have been done. Table 3 summarizes some study parameters. Specific contributions have been done by researches, including from Brazil. However, Brazilian contribution would be more powerful if some internal barriers were overcome. When all this problems will be solved, Brazil will be able to do a great jump in international market as competitive economy.

\subsection{Competitiveness, a Driving Force for Development}

The Global Competitiveness Index (GCI) is a parameter to evaluate the economy of a country and its capacity of development. The World Economic Forum defines competitiveness as "the set of institutions, policies, and factors that determine the level of productivity of a country" [35]. In Figure 4 is presented a comparative of competitiveness between the ten richest countries (TOP10) and Brazil.

Nowadays, Brazil places at 53th position in CGI index (total of 142 countries). Among those pillars, Innovation presents the lowest score, which means that deep structural reforms must be done in order to take Brazil to upper positions and consolidate itself as a solid player in the world market. These reforms can be summarized in four key challenges as political, ideological, economic and technological.

In political aspect, due to the increase of Brazilian population and their life expectation, the investment in renewable technologies competes with others national issues as forethought reform, minimum salary, education, public health and labor reform. In addition, these issues are usually used by opposition groups to wear off the government.

By ideological view, the acceptation confronts with sustainability. The welfare of society is driven by minority groups with political and financial power. If a project looks to supply the poorest population (with lack of information, culture, health, dignity), however eventually strikes any interest of that minority, they will do everything to block it and the project hardly will be done.

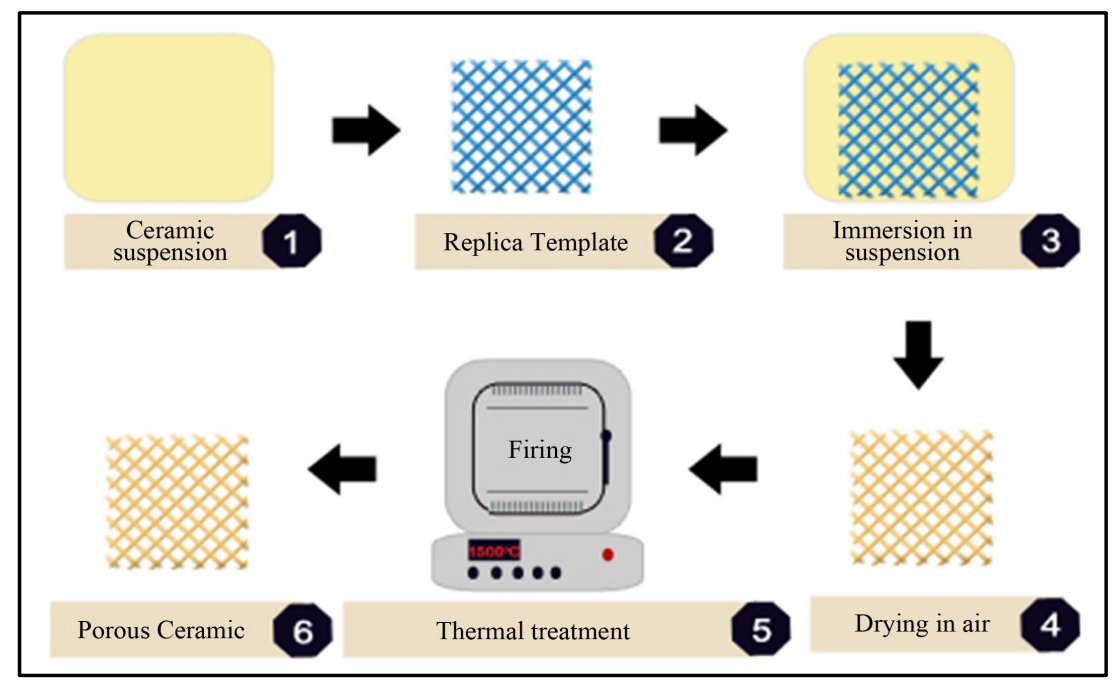

Figure 3. Overview of replica method. 
Table 3. Some studies about colloidal processing of REOs from literature.

\begin{tabular}{|c|c|c|c|c|c|}
\hline Compound & GDC [36] & Lu:Eu [37] & YAG [38] & $\mathrm{Y}_{2} \mathrm{O}_{3}[39]$ & Y:Ce [40] \\
\hline Processing & Tape casting & Slip casting & Slip casting & Replica & - \\
\hline pH & 7.0 & $9-10$ & $9-11$ & 10.0 & - \\
\hline$\zeta(|\mathbf{m v}|)$ & 40.0 & - & - & 56.0 & - \\
\hline$\%$ Vol & 23.0 & $5-10$ & 23.0 & 30.0 & 40.0 \\
\hline Disp. (wt\%) & $1.0 \%$ (PAA) & $1.0 \%$ (PMA) & $1.5 \%$ (PAA) & - & - \\
\hline Binder (wt\%) & $5.0 \%$ (PVA) & - & - & $0.5 \%$ (CMC) & - \\
\hline Plast. (wt\%) & 5\% (PEG) & - & - & _ & - \\
\hline
\end{tabular}

$\zeta$ : Zeta potential; \%vol: solids load in volume percent; Disp.: dispersant dosage in weight percent; Plast.: plasticizer in weight percent; (-) parameter not evaluated, or not divulgated.

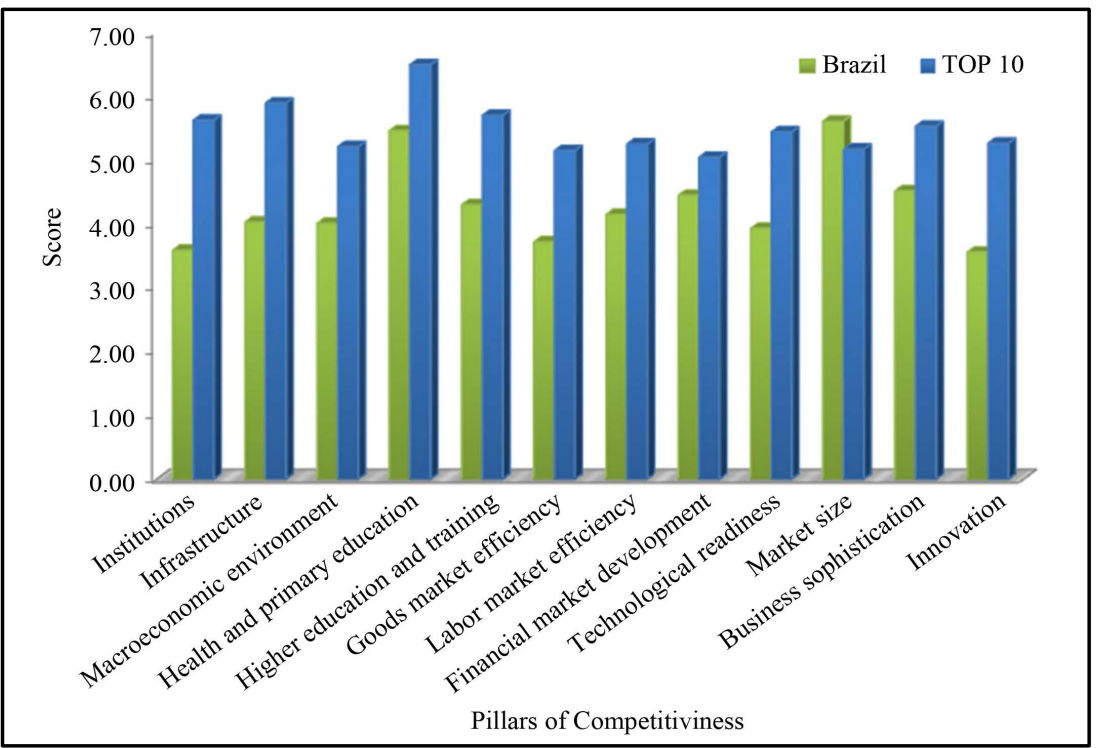

Figure 4. The 12 pillars of competitiveness.

A great concern in industrial market consists in a lack of fiscal incentives for medium or small companies to invest in renewable technologies. In this scenario, only multinational companies are able to research and implement innovative and renewable technologies.

Nowadays Brazil does not have suitable technology to produce rare earth compounds to supply internal demand. Many oxides have been imported such as yttrium oxide $\left(\mathrm{Y}_{2} \mathrm{O}_{3}\right)$, cerium oxide $\left(\mathrm{CeO}_{2}\right)$, dysprosium oxide $\left(\mathrm{Dy}_{2} \mathrm{O}_{3}\right)$ and also metal alloys as cerium-iron. The main owners of rare earth sources are China, United States, Australia, Malaysia and India, whereas Brazil has only $0.03 \%$ of the total. China has the biggest sources, the most producers and developed a competitive processing technology of rare earth compounds. Figure 5 shows the main countries owning rare earth sources in the world.

Even though Brazilian market of rare earth has not been consolidated yet, many efforts have been done by universities and institutes to develop competitive technology to design materials based on rare earth elements [38] [40] [41]-[44]. As shown in Figure 6 [45], in the last three years Brazilian researches have published in scientific and technological periodicals the majority of papers concerning in rare earth technology. In addition, the investigation to create a suitable method to produce PCBL based on REO.

Face to a global challenge which is waste management, this work aims to present the perspectives on development of rare earth porous burners for lighting in Brazil. In addition, the use of biogas is an alternative to convert waste to energy solution and the welfare and comfort of the society can be maintained by a sustainable program. 


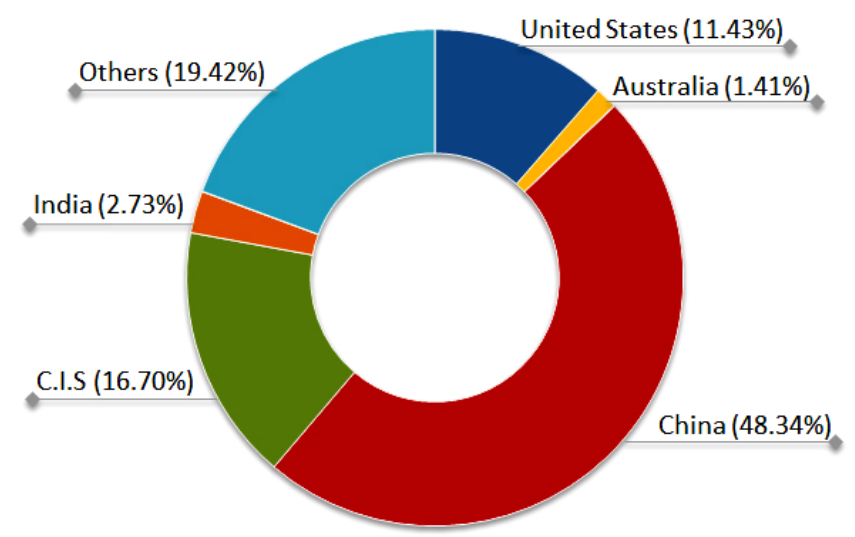

C.I.S: Commonwealth of Independent States; Others: total sum of countries with small percent of sources.

Figure 5. The main world owners of rare earth sources.

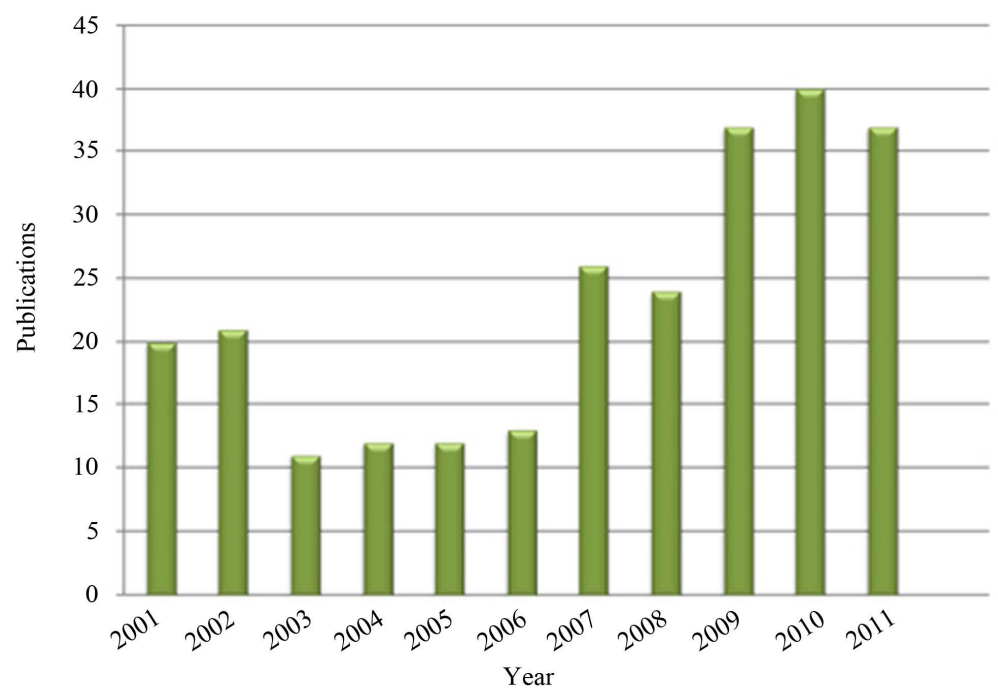

Figure 6. Brazilian publications in national and international scientific and technological periodicals about rare earth technology [45].

\subsection{Materials and Methods}

A mixture of yttrium rare earth carbonate (CaYTR), a raw material achieved from monazite processing supplied by Nuclemon (Nuclebrás de Monazita e Associados, Brazil). The thermal processing condition of CaYTR powders were determinate by Thermal Gravimetric and Differential Analyses (TGA/TDA, Setaram S60/38336), with a heating rate of $10^{\circ} \mathrm{C} / \mathrm{min}$, up to $1400^{\circ} \mathrm{C}$ in air atmosphere and having alumina as reference material.

As oxides condition, the powder characterization of yttria rare earth oxides (YTR) was performed by the following technics, Helium Pycnometry (Micrometrics 1330); Scanning Electronic Microscopy (SEM, Philips XL30); X-Ray Fluorescence (XRF, Rigaku RIX 3000); X-Ray Diffraction (XRD, Rigaku Multiflex), with scanning at $1^{\circ} / \mathrm{min}$, range from $10^{\circ}-80^{\circ}(2 \theta)$, Cu-K $\alpha$ radiation; Photon Correlation Spectroscopy (PCS, Zeta PALS Analyzer, Brookhaven Instruments). For PCS, diluted aqueous solutions with 0.01 vol\% of particles were prepared at $\mathrm{pH} 10.5$ by adding $\mathrm{NaOH}$ solution $(0.5 \mathrm{M})$. Before measurements samples were homogenized in ball mill for 24 h (optimized time), using alumina spheres; Specific Surface Area, by BET method (SSA, Micrometrics ASAP 2010). In addition to SSA, theoretical mean particle diameter $\left(d_{B E T}\right)$ was determinate by BET equation (Equation (1)), which considers particles having spherical and homogeny morphology. Besides, based on $d_{B E T}$ result was calculated the agglomeration factor (Fag) as shown in Equation (2). 


$$
d_{B E T}=\frac{6}{\rho_{t} \cdot S_{M}}[\mu \mathrm{m}]
$$

where: $d_{B E T}=$ theoretical mean particle diameter $(\mu \mathrm{m}) ; \rho_{t}=$ theoretical density $\left(\mathrm{g} \cdot \mathrm{cm}^{-3}\right) ; S_{M}=$ Specific Surface Area $\left(\mathrm{m}^{2} \cdot \mathrm{g}^{-1}\right)$.

$$
F_{a g}=\frac{d_{50}}{d_{B E T}}
$$

where: $d_{50}=$ Experimental mean particle diameter $(\mu \mathrm{m}) ; d_{B E T}=$ Theoretical mean particle diameter $(\mu \mathrm{m})$; Rheological behavior of YTR suspensions was performed with a rheometer (Haake RS600, Thermo Scientific, Germany). The sensor system consisted on a double cone rotor and a stationary plate (DC60/1 ${ }^{\circ}$ ). Suspensions characterization carried on by flow curves in a control rate mode (CR). Measurements were performed at $25^{\circ} \mathrm{C}$ by increasing the shear rate from 0 to $1000 \mathrm{~s}^{-1}$ in $5 \mathrm{~min}$, holding at $1000 \mathrm{~s}^{-1}$ for $2 \mathrm{~min}$ and returning to 0 in $5 \mathrm{~min}$. For each CR mode 200 points were measured.

In replica method, a cotton-nylon netting template (TNA) was coated with YTR suspension and after squeezing out the excess; the structure was dried and subjected to careful thermal treatment in a vertical furnace (Lindberg/Blue M), wherein conditions were based on thermal and gravimetrical analysis (TGA/TDA) results of TNA. Sintered samples surface and microstructure were evaluated by stereoscope (Jena GSZ, Carl Zeiss) and SEM.

Light emission by thermal stimulation (thermoluminescence) of YTR powders was performed by TL reader (Risø TL/OSL-DA-20). The samples were evaluated at a heating rate of $10^{\circ} \mathrm{C} / \mathrm{s}$ until $400^{\circ} \mathrm{C}$ in environmental atmosphere.

\section{Results and Discussion}

Thermal decomposition of CaTR powders (from carbonate to oxide) until $1200^{\circ} \mathrm{C}$ is shown in Figure 7. In TG line was observed a continuous decomposition behavior until $700^{\circ} \mathrm{C}(47 \%)$. Besides DTG line presented two maximum decomposition peaks around $250^{\circ} \mathrm{C}$ and $600^{\circ} \mathrm{C}$. The last one corresponds to the transition from carbonate to oxide state of powders as shown in TDA line (endothermic peak). Finally, from $700^{\circ} \mathrm{C}$ until $1200^{\circ} \mathrm{C}$ no considerable changes concerning loss of mass and structural changes were observed. Sprycha et al. [46] found similar decomposition behavior with yttrium carbonate. Furthermore, based on these results thermal treatment conditions of CaTR powders was set as $10^{\circ} \mathrm{C}$ min until $750^{\circ} \mathrm{C} / 3 \mathrm{~h}$ (air atmosphere).

Figure 8 shows the diffraction patterns of rare earth carbonate as received and after calcination at $750^{\circ} \mathrm{C} / 3 \mathrm{~h}$ by XRD. As a result, at Figure 7(a) are shown relative peaks of Y, Dy and Er carbonates, in which yttrium carbonate peaks were majority. Besides, dysprosium peaks were the most intense $\left(\theta=23^{\circ}\right)$, whereas erbium presented the less intensity. However, after calcination at $750^{\circ} \mathrm{C} / 3 \mathrm{~h}$, where yttrium-rare earth carbonate became yttria —rare earth oxides resulted in a different diffraction pattern. As yttrium-rare earth elements (Y, Dy, Tb, Er, Eu) presents similar chemical and physic proprieties, including inter planar distances and yttria was the major constituent of the ceramic material, only diffraction peaks related to yttria was identified by XRD technique. At the present condition, the others diffraction peaks compounds were overwritten by yttria peaks. A refinement method as Rietveld should be suitable in order to identify inter-planar distances of the major constituents one by one.

X-ray fluorescence (XRF) result showed that YTR powders have a majority concentration of $\mathrm{Y}_{2} \mathrm{O}_{3}(56.6 \mathrm{wt} \% \pm$ $0.1 \mathrm{wt} \%)$ and $\mathrm{Dy}_{2} \mathrm{O}_{3}(19.4 \mathrm{wt} \% \pm 0.5 \mathrm{wt} \%)$. Others rare earths are $\mathrm{Er}_{2} \mathrm{O}_{3}(6.5 \mathrm{wt} \% \pm 0.1 \mathrm{wt} \%), \mathrm{Lu}_{2} \mathrm{O}_{3}(4.1 \mathrm{wt} \% \pm$ $0.4 \mathrm{wt} \%), \mathrm{Ho}_{2} \mathrm{O}_{3}(3.1 \mathrm{wt} \% \pm 0.1 \mathrm{wt} \%), \mathrm{Yb}_{2} \mathrm{O}_{3}$ (wt\%). The sum of other compounds was around $13.4 \mathrm{wt} \%$ (each one concentration less than $1 \mathrm{wt} \%)$. Yttria is very used as matrix for luminescent phosphors as $\mathrm{Eu}^{3+}, \mathrm{Tb}^{3+}, \mathrm{Er}^{3+}$, $\mathrm{Dy}^{3+}$ due to its physical and chemical proprieties are quite similar to REOs. In addition, $\mathrm{Dy}_{2} \mathrm{O}_{3}$ shows yellow emission spectrum, which color according to International Commission on Illumination (CIE) [47] and International Organization for Standardization (ISO) [48], is suitable for human eyes accommodation as subject of lighting. Thus, based on this information, YTR has a great potential to be used as gas burners for lighting.

Mean particle size diameter of YTR powders by PCS is shown in Figure 9(a). As a result, YTR powders consists in broad nano sized particle distribution with a mean diameter $\left(d_{50}\right)$ of $722.6 \mathrm{~nm}$. The size difference (Span) between minor $\left(d_{10}\right)$ and major $\left(d_{90}\right)$ size distributions was $294.1 \mathrm{~nm}$. In addition, relative span $\left(S p a n / d_{50}\right)$ was 0.41 , which means that the difference was almost a half of $d_{50}$. Further, specific surface area by BET method and real 


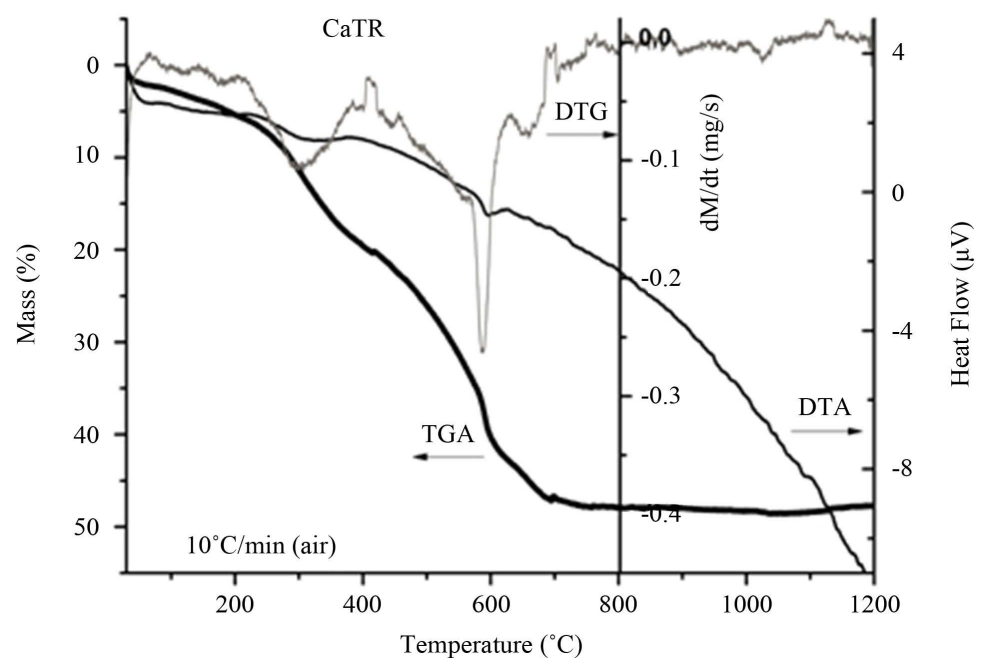

Figure 7. Thermal decomposition of CaTR powders until $1200^{\circ} \mathrm{C}$ by TGA/TDA.

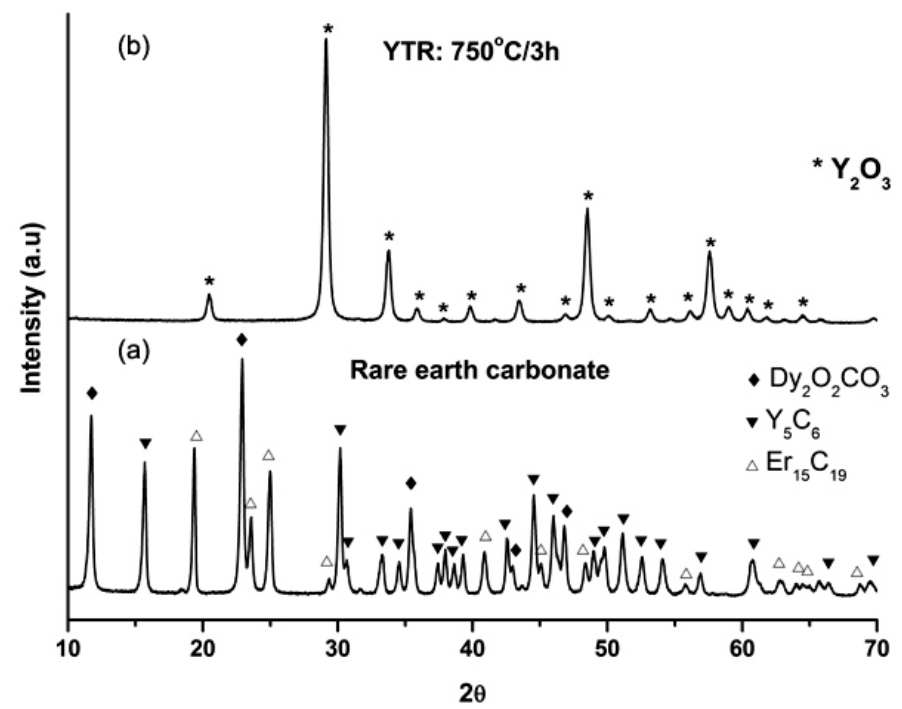

Figure 8. Comparative of diffraction patterns of rare earths carbonate as received with after calcination at $750^{\circ} \mathrm{C} / 3 \mathrm{~h}$ yttria-rare earth oxide.

density were $20.45 \mathrm{~m}^{2} \cdot \mathrm{g}^{-1}$ and $6.03 \mathrm{~g} \cdot \mathrm{cm}^{-3}$ respectively. High density of powders was due to high atomic weight of rare earth elements (Y, Dy, Er, Lu). Comparing calculated mean particle diameter $\left(d_{B E T}=48.7 \mathrm{~nm}\right)$ from Equation (1) with experimental $\left(d_{50}=722.6 \mathrm{~nm}\right)$ from PCS the difference was $673.9 \mathrm{~nm}$. As a consequence high agglomeration factor $\left(\mathrm{F}_{\mathrm{ag}}\right)$ of 14.8 was achieved, which means the particles were much agglomerated. Besides, the morphology of particles can contribute to agglomeration state as shown by Scanning Electronic Microscopy (SEM) of YTR powders (Figure 9(b)). As dry powders YTR presents agglomerates of particles larger than $2 \mu \mathrm{m}$ with morphology like board shape. However, the board shape agglomerates are broken down as dispersing in water (based on stability condition). As a consequence, a broad distribution of particles size is established. Furthermore, YTR powders present particle size distribution that supplies a suitable packing of particles, as well as a densification condition as sintering.

The flow behavior of 25 vol\% YTR suspensions prepared with 0 - $0.7 \mathrm{wt} \%$ of CMC is shown in Figure 10. All CMC concentrations shifted the flow behavior from linear (no CMC) to shear thinning, which could be fitted to Herschel-Bulkley model [49] (Figure 10(a)). In addition, shear thinning suspensions presented an area between up and down curves, which was basically due to breaking down of agglomerates formed by CMC molecules and realignment of particles when subject of shear stress/rate. By viscosity curves as shown in Figure 10(b) the CMC 

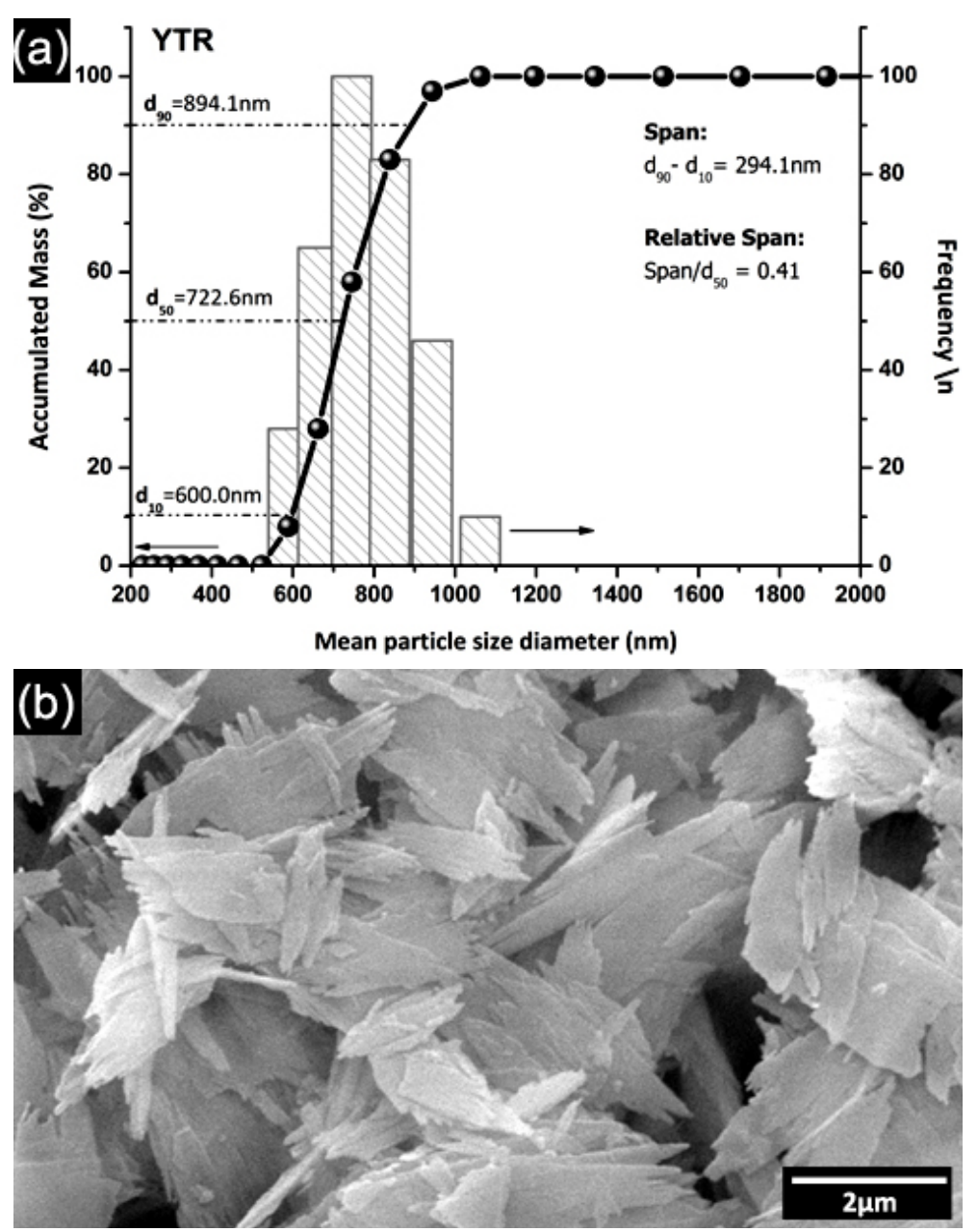

Figure 9. Particle size characterization of YTR powders after thermal processing. (a) Mean particle size distribution by PCS; (b) micrograph by SEM showing like board shape agglomerates. CR flow curve of SYTR with 25 vol\%.

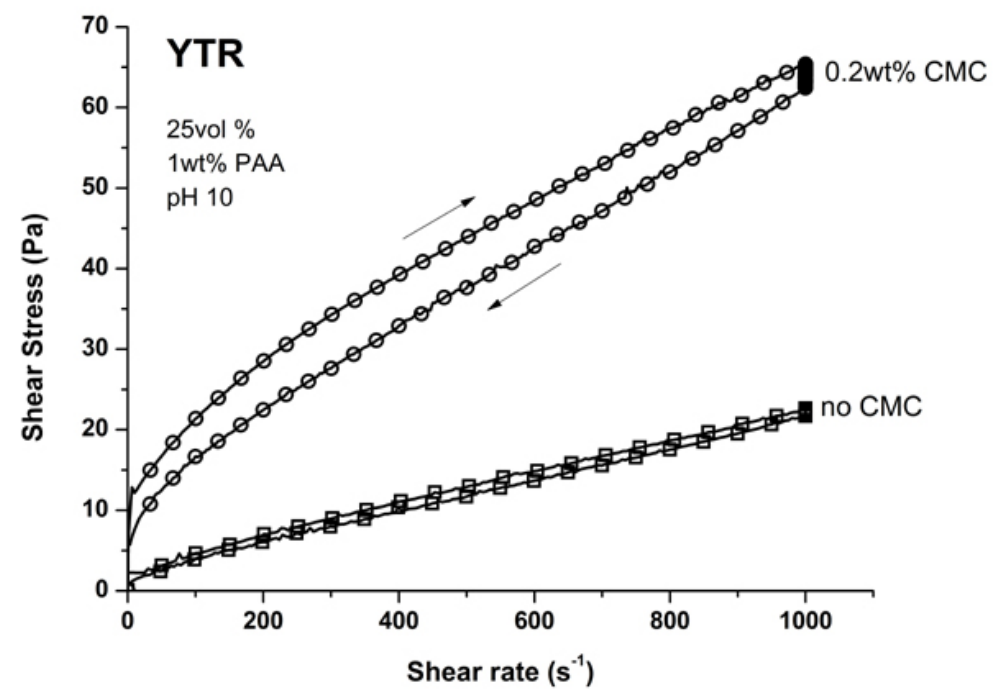

Figure 10. Flow behavior of 25 vol\% of YTR suspensions prepared with $0-0.7$ wt $\%$ CMC. (a) Flow curves in CR mode; (b) Apparent viscosity from $0-1000 \mathrm{~s}^{-1}$. 
effect on flow behavior was clearly defined. At low shear rates $\left(<200 \mathrm{~Pa} \cdot \mathrm{s}^{-1}\right)$ all suspensions based on CMC presented high viscosity values. However, from $200 \mathrm{~Pa} \cdot \mathrm{s}^{-1}$ viscosity started decreasing until a minimum value at $1000 \mathrm{~s}^{-1}$. Furthermore, the viscosity parameter was dependent on shear stress/rate. Shear thinning suspensions are desired for replica, once viscosity is higher in static condition (good adhesion on template surface) and lower when an external force is applied (immersion of template in suspension).

The weight loss of TNA template as a function of temperature was evaluated by thermo gravimetric analyzes until $800^{\circ} \mathrm{C}$ (Figure 11). A slight weight loss is observed at temperatures below $250^{\circ} \mathrm{C}(<4 \mathrm{wt} \%)$. However, a great weight loss (77 wt\%) occurs in a range of temperature from $250^{\circ} \mathrm{C}$ to $350^{\circ} \mathrm{C}$. Apart from this temperature, the weight loss still continues. At $600^{\circ} \mathrm{C}$ the template was totally eliminated (100 wt\%). The thermal decomposition behavior of CNT template confirms that impregnated samples have to be subject of a controlled thermal treatment. The burning out of the organic template and ceramic phase consolidation (sintering) are critical steps into replica processing. Based on these results, the following thermal treatment condition for impregnated templates (temperature/time) was set as $1600^{\circ} \mathrm{C} / 1 \mathrm{~h}$.

Figure 12 shows replica nettings produced from immersion of CNT template (Figure 12(a)) into 25 vol\% YTR suspensions with CMC concentrations of $0.2 \mathrm{wt} \%, 0.5 \mathrm{wt} \%$ and $0.7 \mathrm{wt} \%$ and sintered at $1600^{\circ} \mathrm{C} / 1 \mathrm{~h}$. Samples impregnated with suspensions based on $0.5 \mathrm{wt} \%$ CMC (Figure 12(c)) and $0.7 \mathrm{wt} \%$ CMC (Figure 12(b)) showed many apparent defects (pointed by arrows) such as cracks, trapped cells, heterogeneous distribution of cells and struts, once suspensions presented highly viscous flow. However, by using $0.2 \mathrm{wt} \%$ CMC promoted suitable suspension adhesion on CNT surface, resulting in thin and homogeneous ceramic layer, which did not trap the template cavities and no apparent defects (Figure 12(d) and Figure 12(e)). In addition, the final microstructure consisted in heterogeneous grains size and open porous due to the burning out of template and binder (Figure 12(f)). With cellular structure as well as porous microstructure the final netting has potential to be applied for biogas burners.

Furthermore, the control of the structure of ceramic suspension (stability) drives the forming step as well as the final microstructure. The advantage of the proposed method consists in faster forming, where only one immersion of template into ceramic suspension was required. Complementary methods to improve impregnation as recoating [50], modified template surface [51] and calendering [52] were unnecessary.

Figure 13 shows the emission spectra stimulated by temperature of YTR powders. Whole emission of YTR powders fall on infrared range $(\lambda=750-4300 \mathrm{~nm})$, with $\lambda_{\max }$ at $1000 \mathrm{~nm}$ at $400^{\circ} \mathrm{C}$ behaving as black body. As a solid is heated it starts emitting a continuous radiation at $200^{\circ} \mathrm{C}$, which intensity increases as a function of temperature. Whole radiation is invisible for human eyes (infrared and ultraviolet) and only a small fraction fall on visible spectra. Since YTR is based on a mixture of various rare earth oxides the luminescence result is a sum of all

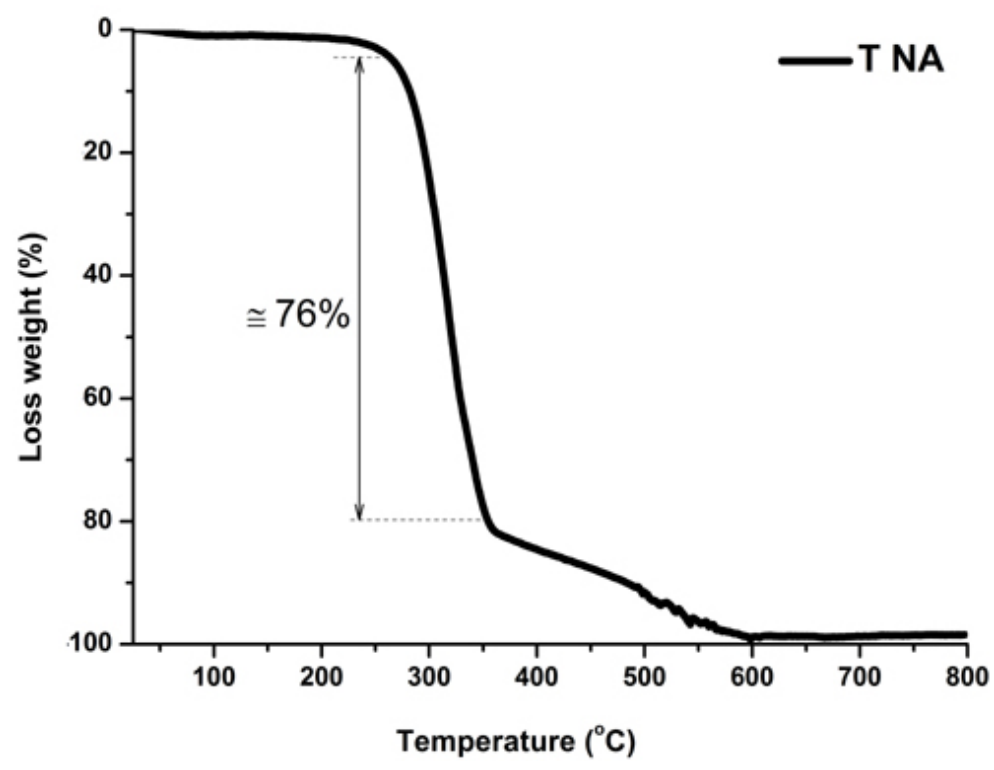

Figure 11. Thermogravimetric analysis of TNA template $\left(10^{\circ} \mathrm{C} / \mathrm{min}\right.$, in air). 

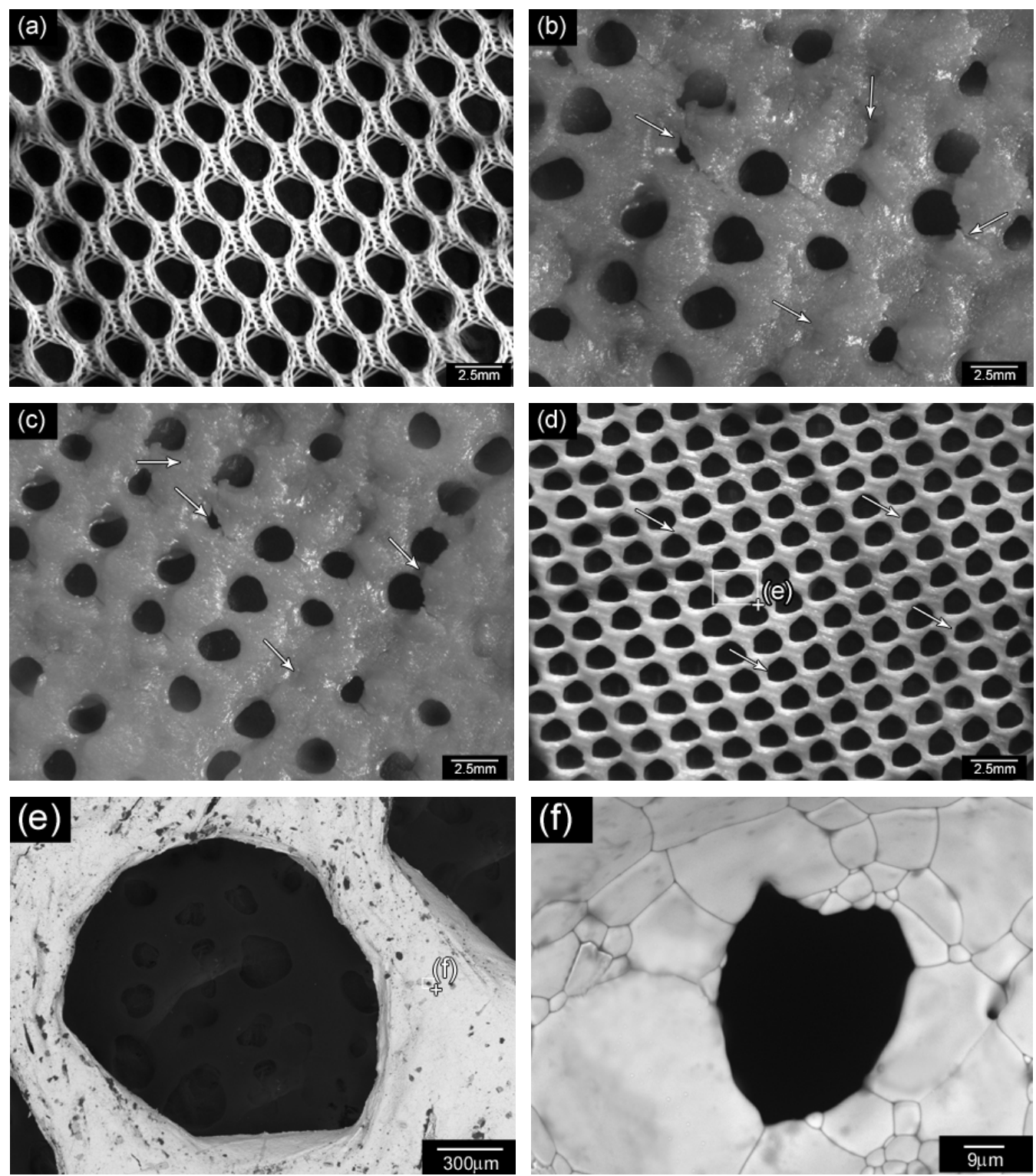

Figure 12. YTR nettings by replica impregnated with 25 vol\% YTR suspensions, having from $0.2-0.7$ wt $\%$ $\mathrm{CMC}$ and sintered at $1600^{\circ} \mathrm{C} / 1 \mathrm{~h}$. (a) CNT template; YTR porous netting architecture produced with (b) 0.7 wt\% CMC; (c) 0.5 wt\% CMC; (d) 0.2 wt\% CMC; (e) micrograph of netting cell from (d); (f) zoom of an open porous from (e) micrograph.

of their spectra. In addition, one rare earth ion can interfere with other rare earth ion emission. Consequently, the maximum intensity and spectra wavelength are damage as well as the light emission performance for gas burners applications.

\section{Conclusion}

As an emerging economy Brazil has been producing thousands of organic waste (biomass), which should be converted onto biogas. Besides, this fuel should be used for lighting by porous ceramic burners contributing to green economy. By technological view, colloidal processing is a viable alternative to produce porous ceramics with potential to be applied as biogas burners. Ceramic suspensions based on a mixture of rare earth oxides-yttria (25 vol\%), $\mathrm{pH}=10,1 \mathrm{wt} \%$ of ammonium poly-acrylic (PAA), $0.2 \mathrm{wt} \%$ of cellulose carboxyl methyl (CMC) presented suitable viscosity to be applied in impregnation process. By replica method near net shape ceramic 


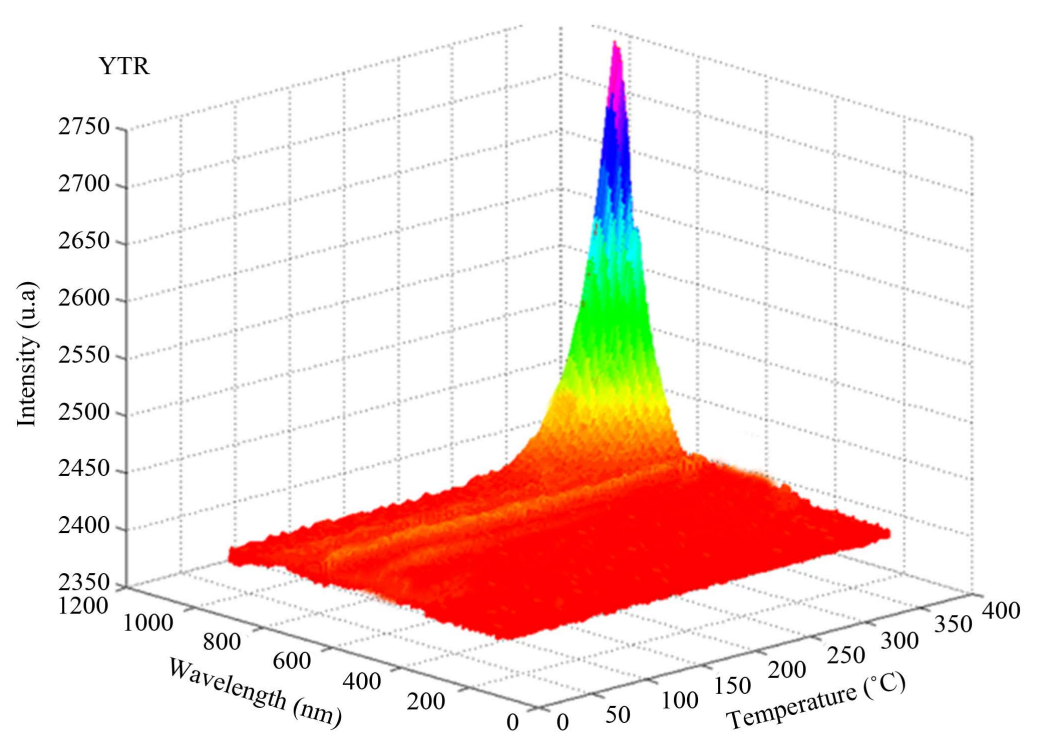

Figure 13. Emission spectra of YTR powders heating at $10^{\circ} \mathrm{C} / \mathrm{s}$ until $400^{\circ} \mathrm{C}$ in environmental atmosphere.

nettings with homogeneous morphology of cells, struts and porous microstructure were produced by only one immersion step and sintering at $1600^{\circ} \mathrm{C} / 1 \mathrm{~h}$. Thermoluminescence evaluation showed that whole emission of YTR powders fell on infrared range $\left(\lambda=750-4300 \mathrm{~nm}\right.$ ), with $\lambda_{\max }$ at $1000 \mathrm{~nm}$ at $400^{\circ} \mathrm{C}$ behaving as black body. The interference between different rare earth ions results in no visible light emission, which damaged the performance for gas burners applications.

\section{Acknowledgements}

We authors are deeply thankful for Dr. Linda Caldas and Dr. Maira Tiemi Yoshizumi to help us with thermoluminescence characterization of yttria powders; MSc. Douglas Will Leite and MSc. William Naville for collaboration with materials characterization by Scanning Electron Microscopy; Dr. Ana Maria Segadães and Dr. Thomaz Restivo for revising this work; The State of São Paulo Research Foundation (FAPESP) and The National Council for Scientific and Technological Development (CNPq) for financial support; in addition, Coordination of High Degree People Improvement (CAPES) for scholarship support of the student Silas Cardoso dos Santos.

\section{References}

[1] Agency, I.E. (2009) Energy Poverty. How to Make Modern Energy Access Universal? International Energy Agency (I.E.A), New York. http://www.se4all.org/wp-content/uploads/2013/09/Special_Excerpt_of_WEO_2010.pdf

[2] Agency, I.E. (2009) Cities, Towns and Renewable Energy. International Energy Agency (I.E.A), Paris. http://www.iea.org/publications/freepublications/publication/Cities2009.pdf

[3] Ministerial, M.E. (2004) PROINFA: Brazilian Program to Universalize the Access of Energy by Stimulating the Use of Renewable Sources from Modern Biomass. Brazil. http://www.mme.gov.br/programas/proinfa/galerias/arquivos/apresentacao/politica_publica.pdf

[4] Cetesb, C.E.S.T. (2006) Biogas-Research and Projects in Brazil. http://www.cetesb.sp.gov.br/biogas/memoria-dos-eventos/135-downloads---biogas:-pesquisas-e-projetos-no-brasil

[5] Walsh, J.L., Ross, C.C., Smith, M.S. and Harper, S.R. (1989) Utilization of Biogas. Biomass, 20, 277-290. http://dx.doi.org/10.1016/0144-4565(89)90067-X

[6] Bruni, E., Jensen, A.P. and Angelidaki, I. (2010) Comparative Study of Mechanical, Hydrothermal, Chemical and Enzymatic Treatments of Digested Biofibers to Improve Biogas Production. Bioresource Technology, 101, 8713-8717. http://dx.doi.org/10.1016/j.biortech.2010.06.108

[7] Bruno, J.C., Ortega-lópez, V. and Coronas, A. (2009) Integration of Absorption Cooling Systems into Micro Gas Turbine Trigeneration Systems Using Biogas: Case Study of a Sewage Treatment Plant. Applied Energy, 86, 837-847. 
http://dx.doi.org/10.1016/j.apenergy.2008.08.007

[8] El-Mashad, H.M. and Zhang, R. (2010) Biogas Production from Co-Digestion of Dairy Manure and Food Waste. Bioresource Technology, 101, 4021-4028. http://dx.doi.org/10.1016/j.biortech.2010.01.027

[9] Hilkiah Igoni, A., Ayotamuno, M. J., Eze, C. L., Ogaji, S.O.T. and Probert, S.D. (2008) Designs of Anaerobic Digesters for Producing Biogas from Municipal Solid-Waste. Applied Energy, 85, 430-438. http://dx.doi.org/10.1016/j.apenergy.2007.07.013

[10] Harasimowicz, M., Orluk, P., Zakrzewska-Trznadel, G. and Chmielewski, A.G. (2007) Application of Polyimide Membranes for Biogas Purification and Enrichment. Journal of Hazardous Materials, 144, 698-702. http://dx.doi.org/10.1016/j.jhazmat.2007.01.098

[11] Lau, C.S., Tsolakis, A. and Wyszynski, M.L. (2011) Biogas Upgrade to Syn-Gas (H2-CO) via Dry and Oxidative Reforming. International Journal of Hydrogen Energy, 36, 397-404. http://dx.doi.org/10.1016/j.ijhydene.2010.09.086

[12] Makaruk, A., Miltner, M. and Harasek, M. (2010) Membrane Biogas Upgrading Processes for the Production of Natural Gas Substitute. Separation and Purification Technology, 74, 83-92. http://dx.doi.org/10.1016/j.seppur.2010.05.010

[13] Pöschl, M., Ward, S. and Owende, P. (2010) Evaluation of Energy Efficiency of Various Biogas Production and Utilization Pathways. Applied Energy, 87, 3305-3321. http://dx.doi.org/10.1016/j.apenergy.2010.05.011

[14] Tippayawong, N. and Thanompongchart, P. (2010) Biogas Quality Upgrade by Simultaneous Removal of $\mathrm{CO}_{2}$ and $\mathrm{H}_{2} \mathrm{~S}$ in a Packed Column Reactor. Energy, 35, 4531-4535. http://dx.doi.org/10.1016/j.energy.2010.04.014

[15] Goldemberg, J. (2006) The Promise of Clean Energy. Energy Policy, 34, 2185-2190. http://dx.doi.org/10.1016/j.enpol.2005.03.009

[16] Goldemberg, J. and Coelho, S.T. (2004) Renewable Energy-Traditional Biomass vs. Modern Biomass. Energy Policy, 32, 711-714. http://dx.doi.org/10.1016/S0301-4215(02)00340-3

[17] Mohamad, A.A. (2005) Combustion in Porous Media: Fundamentals and Applications. In: Ingham and Pop, Eds., Transport Phenomena in Porous Media III, Pergamon, Oxford, 287-304.

[18] Agency, I.E.A. (2010) Renewables Global Status Report. International Energy Agency, New York. http://www.ren21.net/Portals/0/documents/activities/gsr/REN21_GSR_2010_full_revised\%20Sept2010.pdf

[19] Agency, I.E. (2013) Clean Energy Progress Report. IEA Input to the Clean Energy Ministerial. International Energy Agency (I.E.A), New York. www.iea.org/publications/tcep web.pdf

[20] Coelho, S.T. (2010) Waste Rote. Brazilian Bio-Energy Magazine, 55.

[21] Vafai, K. (2005) Handbook of Porous Media. Taylor \& Francis, London. http://dx.doi.org/10.1201/9780415876384

[22] Kotani, Y., Behbahani, H.F. and Takeno, T. (1985) An Excess Enthalpy Flame Combustor for Extended Flow Ranges. Symposium (International) on Combustion, 20, 2025-2033.

[23] Kotani, Y. and Takeno, T. (1982) An Experimental Study on Stability and Combustion Characteristics of an Excess Enthalpy Flame. Symposium (International) on Combustion, 19, 1503-1509.

[24] Mujeebu, M.A., Abdullah, M.Z., Bakar, M. Z. A., Mohamad, A.A. and Abdullah, M.K. (2009) Applications of Porous media Combustion Technology-A Review. Applied Energy, 86, 1365-1375.

http://dx.doi.org/10.1016/j.apenergy.2009.01.017

[25] CENBIO (2011) CENBIO, Centro Nacional de Referência em Biomassa. http://cenbio.iee.usp.br/

[26] Wood, S. and Harris, A.T. (2008) Porous Burners for Lean-Burn Applications. Progress in Energy and Combustion Science, 34, 667-684. http://dx.doi.org/10.1016/j.pecs.2008.04.003

[27] Shan, Z.F., Chen, D.Q., Yu, Y.L., Huang, P., Lin, H. and Wang, Y.S. (2010) Luminescence in Rare Earth-Doped Transparent Glass Ceramics Containing $\mathrm{GdF}_{3}$ Nanocrystals for Lighting Applications. Journal of Materials Science, 45, 2775-2779. http://dx.doi.org/10.1007/s10853-010-4266-1

[28] Zorenko, Y., Mares, J.A., Kucerkova, R., Gorbenko, V., Savchyn, V., Voznyak, T., Nikl, M., Beitlerova, A. and Jurek, K. (2009) Optical, Luminescence and Scintillation Characteristics of Bi-Doped LuAG and YAG Single Crystalline Films. Journal of Physics D: Applied Physics, 42, 075501. http://dx.doi.org/10.1088/0022-3727/42/7/075501

[29] Wang, W.N., Widiyastuti, W., Ogi, T., Lenggoro, W. and Okuyama, K. (2007) Correlations between Crystallite/Particle Size and Photoluminescence Properties of Submicrometer Phosphors. Chemistry of Materials, 19, 17231730. http://dx.doi.org/10.1021/cm062887p

[30] Narisada, K. and Kanaya, S. (1999) Phosphor Handbook. CRC, New York.

[31] Studart, A.R., Gonzenbach, U.T., Tervoort, E. and Gauckler, L.J. (2006) Processing Routes to Macroporous Ceramics: A Review. Journal of the American Ceramic Society, 89, 1771-1789. http://dx.doi.org/10.1111/j.1551-2916.2006.01044.x

[32] Mewis, J. and Wagner, N.J. (2009) Thixotropy. Advances in Colloid and Interface Science, 147-148, 214-227. 
http://dx.doi.org/10.1016/j.cis.2008.09.005

[33] Starov, V.M. and Zhdanov, V.G. (2008) Effective Properties of Suspensions/Emulsions, Porous and Composite Materials. Advances in Colloid and Interface Science, 137, 2-19. http://dx.doi.org/10.1016/j.cis.2006.11.025

[34] Lewis, J.A. (2000) Colloidal Processing of Ceramics. Journal of the American Ceramic Society, 83, 2341-2359. http://dx.doi.org/10.1111/j.1151-2916.2000.tb01560.x

[35] Schwab, K. (2010) The Global Competitiveness Report 2010-2011. In: The Global Competitiveness Report, World Economic Forum, Cologny, 34.

[36] Fu, Y.P., Liu, Y.C. and Hu, S.H. (2009) Aqueous Tape Casting and Crystallization Behavior of Gadolinium-Doped Ceria. Ceramics International, 35, 3153-3159. http://dx.doi.org/10.1016/j.ceramint.2009.05.002

[37] Dulina, N.A., Deineka, T.G., Yavetskiy, R.P., Sergienko, Z.P., Doroshenko, A.G., Mateychenko, P.V., Vovk, O.M. and Matveevskaya, N.A. (2011) Comparison of Dispersants Performance on the Suspension $\mathrm{Lu}_{2} \mathrm{O}_{3}: \mathrm{Eu}^{3+}$ Stability and High-Density Compacts on Their Basis. Ceramics International, 37, 1645-1651. http://dx.doi.org/10.1016/j.ceramint.2011.01.042

[38] Santos, D.R.S., Santos, C.N., de Camargo, A.S.S., Silva, W.F., Santos, W.Q., Vermelho, M.V.D., Astrath, N.G.C., Malacarne, L.C., Li, M.S., Hernandes, A.C., Ibanez, A. and Jacinto, C. (2011) Thermo-Optical Characteristics and Concentration Quenching Effects in $\mathrm{Nd}^{3+}$ Doped Yttrium Calcium Borate Glasses. The Journal of Chemical Physics, 134, 124503-124507. http://dx.doi.org/10.1063/1.3567091

[39] Santos, S.C., Acchar, W., Yamagata, C. and Mello-Castanho, S. (2014) Yttria Nettings by Colloidal Processing. Journal of the European Ceramic Society, 34, 2509-2517. http://dx.doi.org/10.1016/j.jeurceramsoc.2014.03.006

[40] Deters, H., de Camargo, A.S.S., Santos, C.N., Ferrari, C.R., Hernandes, A.C., Ibanez, A., Rinke, M.T. and Eckert, H. (2009) Structural Characterization of Rare-Earth Doped Yttrium Aluminoborate Laser Glasses Using Solid State NMR. Journal of Physical Chemistry C, 113, 16216-16225. http://dx.doi.org/10.1021/jp9032904

[41] Deters, H., de Lima, J.F., Magon, C.J., de Camargoac, A.S.S. and Eckert, H. (2011) Structural Models for Yttrium Aluminium Borate Laser Glasses: NMR and EPR Studies of the System $\left(\mathrm{Y}_{2} \mathrm{O}_{3}\right)_{0.2}-\left(\mathrm{Al}_{2} \mathrm{O}_{3}\right) \mathrm{x}-\left(\mathrm{B}_{2} \mathrm{O}_{3}\right)_{0.8-\mathrm{x}}$. Physical Chemistry Chemical Physics, 13, 16071-16083. http://dx.doi.org/10.1039/c1cp21404g

[42] Moraes, A.P.A., Souza, A.G., Freire, P.T.C., Filho, J.M., M’Peko, J.C., Hernandes, A.C., Antonelli, E., Blair, M.W., Muenchausen, R.E., Jacobsohn, L.G. and Paraguassu, W. (2011) Structural and Optical Properties of Rare EarthDoped $\left(\mathrm{Ba}_{0.77} \mathrm{Ca}_{0.23}\right)_{1-\mathrm{x}}(\mathrm{Sm}, \mathrm{Nd}, \mathrm{Pr}, \mathrm{Yb})_{\mathrm{x}} \mathrm{TiO}_{3}$. Journal of Applied Physics, 109, Article ID: 124102. http://dx.doi.org/10.1063/1.3594710

[43] Santos, D.R.S., Santos, C.N., de Camargo, A.S.S., Silva, W.F., Santos, W.Q., Vermelho, M.V.D., Astrath, N.G.C., Malacarne, L.C., Li, M.S., Hernandes, A.C., Ibanez, A. and Jacinto, C. (2011) Thermo-Optical Characteristics and Concentration Quenching Effects in $\mathrm{Nd}^{3+}$ doped Yttrium Calcium Borate Glasses. Journal of Chemical Physics, 134, Article ID: 124503. http://dx.doi.org/10.1063/1.3567091

[44] Gouveia-Neto, A.S., Bueno, L.A., da Costa, E.B., Silva Jr., E.A., Ferrari, J.L., Lima, K.O. and Gonçalves, R.R. (2010) Generation of Wide Color Gamut Visible Light in Rare-Earth Triply Doped Tantalum Oxide Crystalline Ceramic Powders. Journal of Applied Physics, 107, Article ID: 103539. http://dx.doi.org/10.1063/1.3430998

[45] Elsevier (2013) Scopus. http://www.scopus.com

[46] Sprycha, R., Jablonski, J. and Matijevic, E. (1991) Zeta Potential and Surface Charge of Monodispersed Colloidal Yttrium (III) Oxide and Basic Carbonate. Journal of Colloid and Interface Science, 149, 562-568.

[47] Illumination, I.C.O. (2001) Lighting of Work Places Part 1: Indoor. International Commission on illumination, Vienna.

[48] Standardization, I.O.F. (2002) Lighting for Work Places Part 1: Indoor (ISO: 8995-1: 2002 E). International Commission on illumination, Vienna.

[49] Moreno, R. (2005) Reología de suspensiones cerámicas. Consejo Superior de Investigaciones Científicas, Madrid.

[50] Yao, X.M., Tan, S.H., Huang, Z.R. and Jiang, D.L. (2006) Effect of Recoating Slurry Viscosity on the Properties of Reticulated Porous Silicon Carbide Ceramics. Ceramics International, 32, 137-142. http://dx.doi.org/10.1016/j.ceramint.2005.01.008

[51] Luyten, J., Mullens, S., Cooymans, J., De Wilde, A.M., Thijs, I. and Kemps, R. (2009) Different Methods to Synthesize Ceramic Foams. Journal of the European Ceramic Society, 29, 829-832. http://dx.doi.org/10.1016/i.jeurceramsoc.2008.07.039

[52] Paiva, A.E.M., Sepulveda, P. and Pandolfelli, V.C. (1999) Processing and Thermomechanical Evaluation of FibreReinforced Alumina Filters. Journal of Materials Science, 34, 2641-2649. http://dx.doi.org/10.1023/A:1004613102358 
Scientific Research Publishing (SCIRP) is one of the largest Open Access journal publishers. It is currently publishing more than 200 open access, online, peer-reviewed journals covering a wide range of academic disciplines. SCIRP serves the worldwide academic communities and contributes to the progress and application of science with its publication.

Other selected journals from SCIRP are listed as below. Submit your manuscript to us via either submit@scirp.org or Online Submission Portal.
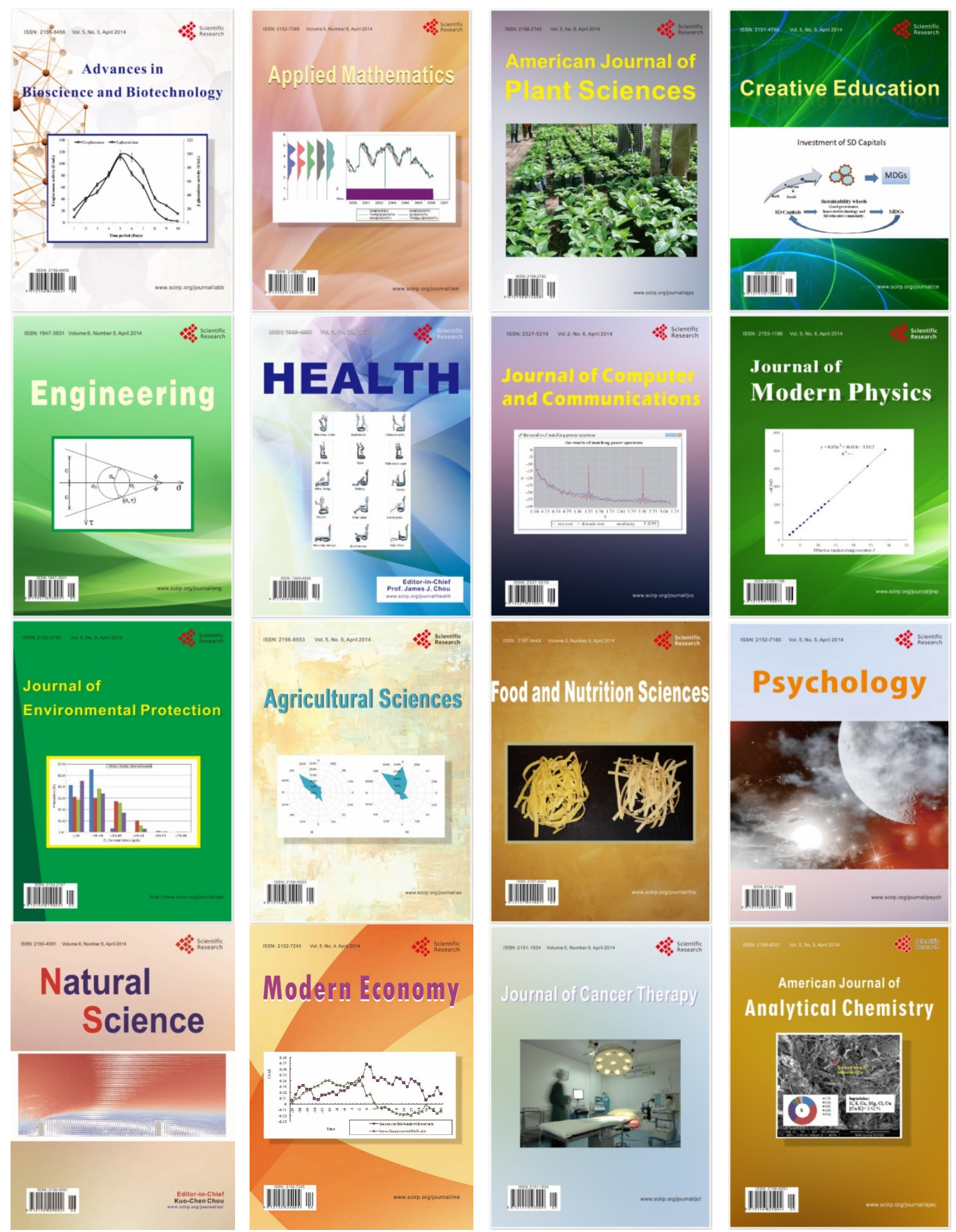